\title{
Regulation of thyrotropin receptor protein expression in insect cells
}

\section{G S Seetharamaiah, S Kaithamana, R K Desai and B S Prabhakar}

Department of Microbiology and Immunology, University of Illinois at Chicago, Chicago, Illinois 60612, USA

(Requests for offprints should be addressed to B S Prabhakar, Department of Microbiology and Immunology, University of Illinois at Chicago, 835 S. Wolcott (M/C 790), Chicago, Illinois 60612, USA; Email: bprabhak@uic.edu)

\begin{abstract}
Expression of large quantities of conformationally intact thyrotropin receptor (TSHR) is essential to understand the structure-function relationship of the receptor. We expressed three different constructs of full-length human TSHR in insect cells: (a) a TSHR cDNA lacking signal sequence (TSHR-ns), (b) a TSHR cDNA containing human TSHR signal sequence (TSHR-hs) and (c) a TSHR cDNA with baculovirus envelope protein encoded signal sequence gp-67 (TSHR-gp). No unique protein band, corresponding to any of these recombinant proteins, was visible upon Coomassie Blue staining after SDS-PAGE. However, Western blot using TSHR specific monoclonal antibody showed unique bands around 80,100 and $100 \mathrm{kDa}$ in TSHR-ns, TSHR-hs and TSHR-gp virus infected insect cells respectively. All three fulllength TSHR proteins could neutralize the TSH
\end{abstract}

binding inhibitory immunoglobulin (TBII) activity from sera of experimental animals. However, only glycosylated proteins (TSHR-hs and TSHR-gp) neutralized the TBII activity of sera from autoimmune thyroid patients, confirming the importance of glycosylation for patient autoantibody reactivity. Expression levels of full-length TSHR proteins were much lower than the levels of similarly produced corresponding ectodomains of TSHR proteins. Southern blot and Northern blot analyses showed that DNA and RNA levels in full-length TSHR virus infected insect cells were comparable to the levels found in cells infected with viruses encoding only the ectodomain of TSHR. These data suggest that full-length TSHR expression is very low and is regulated at the translational level.

Fournal of Molecular Endocrinology (1999) 23, 315-323

\section{INTRODUCTION}

Thyrotropin receptor (TSHR) is the primary autoantigen in Graves' disease and the disease is characterized by autoantibodies to TSHR (Nagayama \& Rapoport 1992, Vassart \& Dumont 1992, Kohn et al. 1995, Prabhakar et al. 1997). Large amounts of functional TSHR are essential to understand the structure-function relationship of the receptor as well as the pathogenesis of Graves' disease. The full-length TSHR has been stably expressed in mammalian cells and binds TSH with high affinity (Nagayama et al. 1989, Perret et al. 1990, Chazenbalk et al. 1996) and is recognized by autoantibodies (Ludgate et al. 1990, Filetti et al. 1991, Tahara et al. 1991, Harfst et al. 1992a, Matsuba et al. 1995). However, the level of expression is low and is insufficient for purification. More- over, attempts to overexpress full-length TSHR in insect cells have not been successful (Harfst et al. 1992a, Huang et al. 1993, Seetharamaiah et al. 1993, Misrahi et al. 1994, Chazenbalk \& Rappoport 1995). In contrast, ectodomain of the TSHR (ETSHR) has been produced in large quantities using bacterial (Takai et al. 1991, Harfst et al. 1992b, Huang et al. 1992, Costagliola et al. 1994, Graves et al. 1995), baculovirus (Huang et al. 1993, Seetharamaiah et al. 1993, Chazenbalk \& Rapoport 1995, Vlase et al. 1995, Seetharamaiah et al. 1997) and mammalian expression systems (Harfst et al. 1992c, Shi et al. 1993, Rapoport et al. 1996, Osuga et al. 1997, Costagliola et al. 1998, Da Costa \& Johnstone 1998). In this report, we describe our efforts to express the full-length human TSHR in insect cells. We studied the effects of glycosylation of TSHR on autoantibody reactivity. To understand the basis for 
the differential expression, we compared DNA and RNA levels in insect cells infected with recombinant virus encoding full-length TSHR and ETSHR. Our data strongly suggest that the level of expression is regulated at the post-transcription level.

\section{MATERIALS AND METHODS}

\section{Source of human sera}

Sera were collected from patients with either primary myxedema (p101 and p103) or Graves' disease (p113-126). Patients were diagnosed using appropriate standard clinical and laboratory criteria. Sera were also obtained from healthy normal volunteers with no family history of thyroid autoimmunity. Sera were stored at $-20{ }^{\circ} \mathrm{C}$ until use.

\section{Cell culture}

Sf9 cells (Gibco BRL, Gaithersburg, MD, USA) were maintained in TNM-FH medium (Sigma, St Louis, MO, USA) supplemented with $10 \%$ fetal bovine serum (Sigma) and antibiotic/antimycotic agents.

\section{Generation of different recombinant baculoviruses}

Figure 1 shows the different TSHR constructs used for the production of recombinant viruses. Construction of recombinant viruses encoding three different ectodomains of human (h) TSHR (ETSHR, TSHR-E and ET-gp) has been previously described (Seetharamaiah et al. 1997). For this study, we constructed three additional recombinant viruses, described below:

(a) TSHR-ns/PVL 1393: a full-length human TSHR cDNA lacking a signal sequence (TSHR-ns) was generated as follows. A cDNA encoding ETSHR lacking the signal sequence, representing nucleotides 64 to 1248, (Seetharamaiah et al. 1993) was digested with SspI to obtain $167 \mathrm{bp}$ BamHI-SspI 5' fragment. Similarly, 2474 bp fulllength human TSHR cDNA (Tahara et al. 1991) was digested with SspI to obtain a $2144 \mathrm{bp}$ SspI-EcoRI 3' fragment. The 167 and $2144 \mathrm{bp}$ cDNA fragments were subcloned into the BamHI-EcoRI site of the baculovirus transfer vector PVL 1393 (Pharmingen, San Diego, CA, USA).

(b) TSHR-hs/PVL 1393: a full-length human TSHR cDNA including human TSHR signal sequence (TSHR-hs) and $100 \mathrm{bp} 5^{\prime}$ upstream



FIGURE 1. Schematic representation of various ectodomain and full-length TSHR constructs. ETSHR, TSHR-E and ET-gp represent TSHR ectodomain encoding amino acids 22-416. Similarly, TSHR-ns, TSHR-hs and TSHR-gp represent full-length TSHR encoding amino acids 22-764. Constructs ETSHR and TSHR-ns lack signal sequence. Both TSHR-E and TSHR-hs have human TSHR signal sequence and 100 bp 5' upstream sequence (hateched bars). ET-gp and TSHR-gp both have baculovirus-encoded signal sequence gp67 (solid bars).

sequence (Tahara et al. 1991) (2474 bp) was subcloned into the EcoRI site of the baculovirus transfer vector PVL 1393 (Pharmingen).

(c) TSHR-gp/pAcGP67B: a full-length human TSHR cDNA lacking the signal sequence, generated as described above, was subcloned into the BamHI-EcoRI site of the baculovirus transfer vector pAcGP67B (Pharmingen), which contains the baculovirus-encoded signal sequence gp67. This construct allows expression of TSHR as a fusion protein containing gp67 signal peptide.

Different recombinant viruses were generated by co-transfecting Sf9 cells with $0.5 \mu \mathrm{g}$ of linearized Baculogold viral DNA (Pharmingen) and either $2 \mu \mathrm{g}$ of TSHR-ns/PVL 1393 DNA, TSHR-hs/PVL 1393 DNA or TSHR-gp/pAcGP67B DNA, according to the manufacturer's protocol. Media containing the recombinant viruses (TSHR-ns, TSHR-hs and TSHR-gp) were harvested after 5 days. The recombinant viruses were further amplified twice to obtain high titered viruses.

\section{Expression of recombinant proteins}

Monolayers of Sf9 cells were infected with different recombinant viruses. After 3-4 days, cells were harvested and lysed by vortexing in lysis buffer 
(30 mM Tris, pH 7.4, $150 \mathrm{mM} \mathrm{NaCl}, 10 \mathrm{mM}$ magnesium acetate, $1 \% \mathrm{NP} 40,5 \mu \mathrm{g} / \mathrm{ml}$ leupeptin, $5 \mu \mathrm{g} / \mathrm{ml}$ aprotinin and $0.5 \mathrm{mM}$ phenyl-methylsulphonyl fluoride). The pellet containing the receptor protein was solubilized in $50 \mathrm{mM}$ Tris, pH 7.4 containing $0.5 \%$ sodium dodecyl sulphate (SDS). Proteins were separated by SDSpolyacrylamide electrophoresis (SDS-PAGE) and either stained with $0 \cdot 1 \%$ Coomassie Blue or subjected to Western blot analysis. For Western blotting, proteins separated by SDS-PAGE were electrophoretically transferred onto nitrocellulose membranes and stained with ETSHR-specific mAb 28 (Seetharamaiah et al. 1995, Whetsell et al. 1999) as described previously (Seetharamaiah et al. 1994). To test the specificity of this reactivity, monoclonal antibody (mAb) 28 was pre-incubated with either ETSHR protein or TSHR-derived synthetic peptide (amino acids 22-41) for $2 \mathrm{~h}$ at room temperature before staining the Western blot. For large-scale protein production, Sf9 cells were grown in suspension cultures and processed as described previously (Seetharamaiah et al. 1993).

\section{Neutralization of TSHR antibodies}

A modified TSH binding inhibitory immunoglobulin (TBII) assay was used to test the ability of TSHR proteins to neutralize TSHR antibodies (Seetharamaiah et al. 1997, 1999). Rabbit antisera $(50 \mu \mathrm{l})$ raised against ETSHR or ET-gp protein or ETSHR-derived peptide p367 (amino acids 367-386), and sera from hypothyroid or hyperthyroid patients, were incubated for $1 \mathrm{~h}$ at room temperature with $5 \times 10^{6}$ lysed insect cells expressing TSHR-ns or TSHR-hs or TSHR-gp proteins. The contents were centrifuged at $14000 \times \boldsymbol{g}$ for $10 \mathrm{~min}$, and the supernatants were tested for their TBII activity using a commercially available radioreceptor assay (RRA) kit (Kronus, Dana Point, CA, USA). Serum samples $(50 \mu \mathrm{l})$, incubated with and without recombinant protein, were mixed with $50 \mu \mathrm{l}$ of solubilized porcine TSHR and incubated at room temperature for $15 \mathrm{~min}$. The contents were mixed with $100 \mu \mathrm{l}$ of radiolabeled TSH (10 000 c.p.m.) and incubated at room temperature for $2 \mathrm{~h}$. Two milliliters of cold precipitating agent $(16.5 \%$ polyethylene glycol in $1 \mathrm{M} \mathrm{NaCl}$ ) was added, vortexed and centrifuged at $1500 \times \boldsymbol{g}$ for $30 \mathrm{~min}$ at $4{ }^{\circ} \mathrm{C}$. The pellet was counted in a gamma counter. For control purposes, sera were also pre-incubated with insect cells infected with wild type (WT) virus before testing for TBII activity. The TBII was calculated as follows: $1-(\%$ receptor bound ${ }^{125} \mathrm{I}-\mathrm{TSH} / \%$ negative reference) $\times 100 \%$.

\section{Titration of recombinant virus}

Virus titer was determined by end-point dilution as described by Summers and Smith (1987). Briefly, Sf9 cells were plated onto 96 -well plates $\left(2 \times 10^{4}\right.$ cells/well). After $2 \mathrm{~h}$, different recombinant viruses were added to wells at dilutions ranging from $10^{-1}$ to $10^{-8}$ and incubated at $26^{\circ} \mathrm{C}$ for 7 days. Cells were monitored daily from day 2 for growth and infection. The highest dilution of virus at which at least $50 \%$ of the cells were infected was considered the end point.

\section{Isolation and purification of total DNA and Southern blot analysis}

The Sf9 cells infected with different recombinant viruses were used for the isolation of DNA at $48 \mathrm{~h}$ post infection. The culture media was removed and $5 \mathrm{ml}$ of lysis buffer $(0 \cdot 03 \mathrm{M}$ Tris $-\mathrm{HCl} \mathrm{pH} 7 \cdot 5$, $0.01 \mathrm{M}$ magnesium acetate and $1.0 \% \mathrm{NP}-40$ ) were added to the cells. The cells were kept on ice for 5 min with intermittent vortexing. The nuclei were pelleted at 2000 r.p.m./3 min, washed with cold PBS and repelleted. The pellet was resuspended in $4.5 \mathrm{ml}$ of extraction buffer $(0.1 \mathrm{M}$ Tris $\mathrm{pH} 7 \cdot 5$, $0.09 \mathrm{M} \mathrm{EDTA}$ and $200 \mathrm{mM} \mathrm{KCl}$ ) containing $200 \mu \mathrm{g} / \mathrm{ml}$ proteinase $\mathrm{K}$ and incubated at $50{ }^{\circ} \mathrm{C}$ for $1 \mathrm{~h}$. The incubation was continued for another $2 \mathrm{~h}$ after the addition of $0.5 \mathrm{ml}$ of $10 \%$ sarkosyl. The DNA containing aqueous phase was extracted twice with phenol/chloroform/isoamyl alcohol and precipitated with $10 \mathrm{ml}$ of absolute ethanol. The DNA was pelleted at 2500 r.p.m. for $20 \mathrm{~min}$ and washed with cold $90 \%$ ethanol. The pellet was suspended in $500 \mu \mathrm{l}$ of $0 \cdot 1 \times$ TE. Five micrograms of total DNA was digested with appropriate restriction enzyme and separated on a $0 \cdot 8 \%$ agarose gel. The DNA was stained with ethidium bromide, exposed to u.v. light and photographed. The gel was depurinated and transferred under alkaline conditions to a nylon membrane ( $\mathrm{S} \& \mathrm{~S}$, Keene, NH, USA). Southern blot analysis was performed using standard procedures (Sambrook et al. 1989). The blot was prehybridized at $42{ }^{\circ} \mathrm{C}$ for $6 \mathrm{~h}$ in buffer containing $5 \times$ Denhardt's solution $\left(25 \mathrm{mM} \mathrm{KPO}_{4} \mathrm{pH} 7 \cdot 4,5 \times \mathrm{SSC}, 100 \mu \mathrm{g} /\right.$ $\mathrm{ml}$ of salmon sperm DNA and 50\% formamide). A $1.2 \mathrm{~kb}$ cDNA encoding ETSHR was labeled with $\left[\alpha-{ }^{32} \mathrm{P}\right] \mathrm{dCTP}$ by using prime labeling kit (Promega, Madison, WI, USA), added to the blot $\left(5 \times 10^{6}\right.$ c.p.m. $\left./ \mathrm{ml}\right)$, and was hybridized for $16 \mathrm{~h}$ at $42{ }^{\circ} \mathrm{C}$. The blot was then washed twice in $2 \times \mathrm{SSC}$ $(1 \times \mathrm{SSC}$ in $0.15 \mathrm{M}$ sodium chloride plus $0.015 \mathrm{M}$ sodium citrate) $-0 \cdot 1 \% \mathrm{SDS}$ at room temperature for $20 \mathrm{~min}$ and twice in $1 \times \mathrm{SSC}-0 \cdot 1 \% \mathrm{SDS}$ at $65^{\circ} \mathrm{C}$ 
for $20 \mathrm{~min}$. The blots were exposed to Kodak $\mathrm{X}$-AR film at $-80{ }^{\circ} \mathrm{C}$.

\section{Northern blot analysis}

Total RNA was isolated from Sf9 cells infected with different recombinant viruses using RNeasy kit (Qiagen, Santa Clarita, CA, USA) as recommended by the manufacturer. Ten micrograms of each RNA preparation were analyzed by electrophoresis on a $1 \cdot 2 \%$ formaldehyde gel, stained with ethidium bromide, and photographed. The RNA was then transferred to a nylon membrane $(\mathrm{S} \& \mathrm{~S})$ by capillary method. The prehybridization, hybridization and autoradiography were carried out as described above for Southern analysis.

\section{RESULTS}

\section{Expression of TSHR proteins}

Expression of recombinant proteins was assessed by SDS-PAGE and Western blot analysis. Different recombinant virus infected insect cells were lysed in a lysis buffer, solubilized in SDS buffer and subjected to SDS-PAGE. As reported previously (Seetharamaiah et al. 1993, 1997), we observed major protein bands around 50 and $63 \mathrm{kDa}$ in ETSHR and ET-gp virus infected insect cell extracts respectively (Fig. 2A, lanes 1 and 3). There was no apparent unique protein band corresponding to either TSHR-E (ectodomain with human signal sequence) or any of the full-length TSHR proteins. On an immunoblot using an ETSHR-specific monoclonal antibody (mAb 28) (Seetharamaiah et al. 1995) the 50 and $63 \mathrm{kDa}$ proteins were identified as non-glycosylated and glycosylated forms of ETSHR protein respectively (Fig. 2B, lanes 1-3). Although protein bands corresponding to TSHR-E, and full-length TSHR proteins were not visible on the Coomassie Blue stained gel, they could be readily detected on a Western blot (Fig. 2B, lanes 2 and 4-6). A unique band, around $80 \mathrm{kDa}$, was detected on Western blot of cells infected with recombinant virus containing full-length TSHR without any signal sequence (TSHR-ns) (Fig. 2B, lane 4). The observed molecular mass of $80 \mathrm{kDa}$ agrees closely with the expected size based on the predicted amino acid sequence (amino acids 22-764). Similarly, cells infected with virus containing full-length TSHR with either human or gp67 signal sequence showed a doublet around 95$100 \mathrm{kDa}$ (Fig. 2B, lanes 5 and 6 respectively). This higher molecular mass of TSHR-hs and TSHR-gp proteins is most likely due to glycosylation of the protein. The reactivity of recombinant proteins in Western blot was specific and could be completely

\section{A}

$\begin{array}{lllllll}M & 1 & 2 & 3 & 4 & 5 & 6\end{array}$
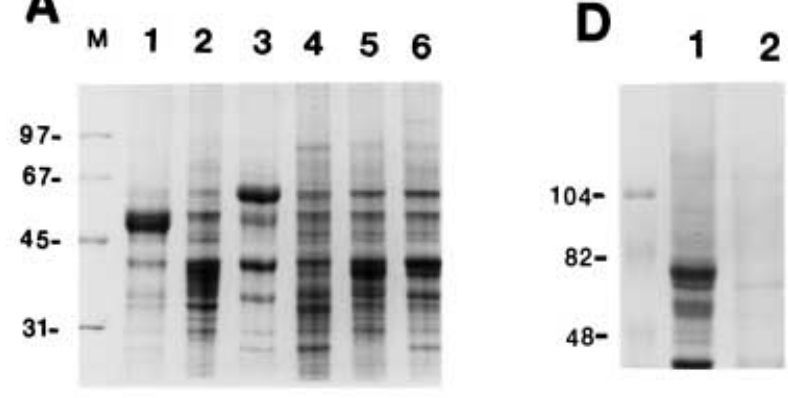

B
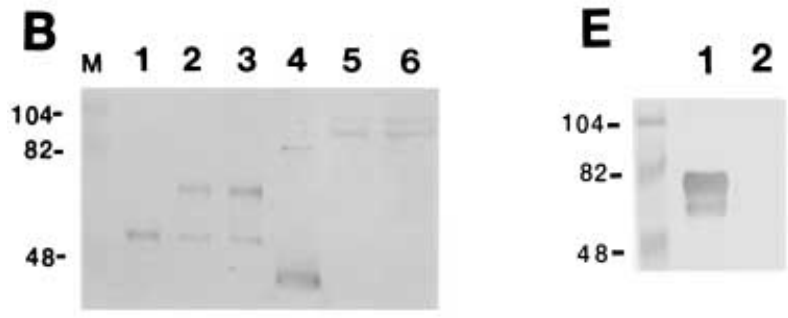

C
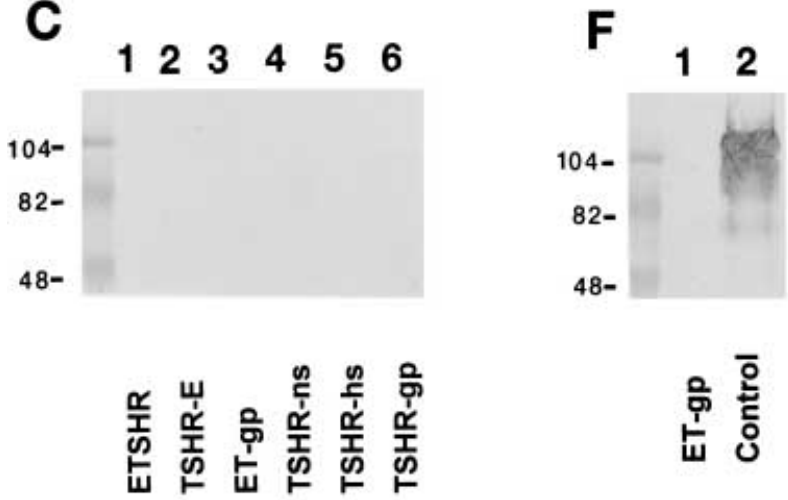

FIGURE 2. Expression of the human TSHR protein. Proteins from recombinant virus infected Sf9 cells were separated on a $10 \%$ SDS gel and stained with Coomassie Blue (A and D) or subjected to Western blot analysis using ETSHR-specific mAb 28 (B and E) or subjected to Western blot analysis using control mAb specific for Pemphigus vulgaris antigen (PVA) (C and F). For Western blot, significantly lower concentrations of ectodomains were used to obtain band intensities comparable with those of full-length TSHR proteins. In (A), (B) and (C), lanes 1-6 represent ETSHR,

TSHR-E, ET-gp, TSHR-ns, TSHR-hs and TSHR-gp respectively. In (D), (E) and (F), lanes 1 and 2 represent ET-gp and control antigen PVA respectively. The left lane in each panel (M) represents molecular mass markers.

removed by pre-incubating mAb 28 either with the ETSHR protein or with an ETSHR-derived synthetic peptide (amino acid residues 22-41) (not 
TABLE 1. Inhibition of TBII activity. Serum samples $(50 \mu \mathrm{l})$ from rabbits immunized with ETSHR protein, or with peptide 367 (amino acids 367-386) or with ET-gp or from patients with hypothyroidism (p101 and p103) or hyperthyroidism (p113-p126) were pre-incubated with $5 \times 10^{6}$ insect cells producing either TSHR-ns, TSHR-hs, TSHR-gp or wild type (WT) polyhedrin protein and then tested for TBII activity in a radioreceptor assay. TBII values represent mean of duplicate determinations for each serum sample. A total of 10000 c.p.m. of ${ }^{125}$ I-bTSH was used per assay sample. Specific mean c.p.m. values for normal rabbit serum and normal human serum were 3350 and 3825 respectively. Specific mean c.p.m. values for test samples are given in parentheses

$\%$ TBII

(c.p.m.)

Serum sample

Experimental

Anti-ETSHR1

Anti-ETSHR2

Anti-367

Anti-ET-gp1

Anti-ET-gp2

Patients

P101

P103

P113

P114

P117

P118

P119

P120

P121

P123

P124

$\mathrm{P} 125$

P126
\% TBII (c.p.m.) after incubation with

\begin{tabular}{|c|c|c|c|}
\hline TSHR-ns & TSHR-hs & TSH-gp & Control (WT) \\
\hline$-2 \cdot 8(3694)$ & $3 \cdot 4(3236)$ & $-2 \cdot 3(3427)$ & $51 \cdot 5(1624)$ \\
\hline$-1 \cdot 8(3410)$ & $2 \cdot 6(3262)$ & $2 \cdot 5(3266)$ & $42 \cdot 7$ (1919) \\
\hline $4 \cdot 9(3185)$ & $5 \cdot 1(3179)$ & $3 \cdot 6(3229)$ & $37 \cdot 9(2080)$ \\
\hline $15 \cdot 1(2844)$ & $9 \cdot 0(3048)$ & $2 \cdot 0(3283)$ & $88 \cdot 2(395)$ \\
\hline $11 \cdot 0(2981)$ & $6 \cdot 2(3142)$ & $0.9(3319)$ & $82 \cdot 6(582)$ \\
\hline $85 \cdot 1(570)$ & $7 \cdot 7(3530)$ & $-3 \cdot 7(3966)$ & $82.9(654)$ \\
\hline $70 \cdot 6(1124)$ & $32 \cdot 5(2582)$ & $27 \cdot 9(2757)$ & $72 \cdot 7(1044)$ \\
\hline $33 \cdot 2(2555)$ & $-1 \cdot 5(3882)$ & $-1 \cdot 8(3894)$ & $31 \cdot 8(2624)$ \\
\hline $58 \cdot 3(1595)$ & $13 \cdot 9(3293)$ & $0 \cdot 9(3790)$ & $59 \cdot 4(1553)$ \\
\hline $69 \cdot 7(1159)$ & $12 \cdot 5(3347)$ & $4 \cdot 1(3668)$ & $72 \cdot 6(1048)$ \\
\hline $44 \cdot 9(2107)$ & $11 \cdot 2(3396)$ & $-2 \cdot 5(3729)$ & $49 \cdot 1(1947)$ \\
\hline $78 \cdot 8(810)$ & $46 \cdot 7(2038)$ & $40 \cdot 4(2280)$ & $80 \cdot 5(746)$ \\
\hline $68 \cdot 1(1220)$ & $24 \cdot 5(2888)$ & $11.7(3377)$ & $69 \cdot 3(1174)$ \\
\hline $22 \cdot 8(2953)$ & $4 \cdot 5(3653)$ & $13 \cdot 1(3324)$ & $27 \cdot 7(2765)$ \\
\hline $39 \cdot 5(2314)$ & $12 \cdot 0(3366)$ & $3 \cdot 2(3702)$ & $42 \cdot 7(2191)$ \\
\hline $45 \cdot 6(2080)$ & $11 \cdot 7(3377)$ & $7 \cdot 3(3545)$ & $44 \cdot 5(2123)$ \\
\hline $54 \cdot 8(1729)$ & $7 \cdot 2(3549)$ & $-1 \cdot 0(3863)$ & $53 \cdot 9(1763)$ \\
\hline $87 \cdot 4(482)$ & $85 \cdot 8(543)$ & $80 \cdot 1(761)$ & $84 \cdot 6(589)$ \\
\hline
\end{tabular}

shown). The specificity of reactivity of TSHR recombinant proteins with $\mathrm{mAb} 28$ was further confirmed when mAb 28 reacted only with ET-gp (Fig. 2E, lane 1) but not with baculovirus-expressed Pemphigus vulgaris antigen (PVA) (Fig. 2D and E, lane 2) (Memar et al. 1996). Similarly, the mAb specific for PVA reacted with $130 \mathrm{kDa}$ PVA (Fig. 2D and F, lane 2) and not with TSHR (Fig. 2C, lanes 1-6 and 2F, lane 1).

\section{Reversal of TBII activity of experimental and patients' sera}

Earlier we had shown that all three ectodomains could neutralize the TBII activity of experimental sera, but only TSHR-E and ET-gp, the glycosylated ectodomains, could neutralize TBII in patients' sera (Seetharamaiah et al. 1997). Therefore, to see whether glycosylated full-length protein is required for patient autoantibody reactivity, we tested the ability of full-length TSHR proteins to reverse the TBII activity of experimental antibodies in a modified RRA. As shown in Table 1, pre-incubating the $\alpha$-ETSHR or $\alpha$-ET-gp or an $\alpha$-peptide (amino acids 367-386) sera with either
TSHR-ns, TSHR-hs or TSHR-gp protein resulted in almost complete neutralization of the antibodies and prevented them from blocking TSH binding to the TSHR. Encouraged by these results, next we tested these recombinant proteins for their ability to neutralize autoantibodies to TSHR in the sera of hypothyroid and hyperthyroid patients. As shown in Table 1, TBII activity remained unchanged in all 13 sera when they were pre-incubated with the non-glycosylated TSHR-ns protein or with proteins from control cells infected with wild-type baculovirus. In contrast, the glycosylated TSHR-hs and TSHR-gp proteins significantly neutralized the TSHR autoantibodies in 12 of the 13 sera tested. These data further confirmed earlier studies that glycosylation of the human TSHR is important for autoantibody reactivity (Rapoport et al. 1996, Seetharamaiah et al. 1997).

\section{Replicative ability of different recombinant viruses}

Although we were successful in expressing fulllength TSHR protein, the level of expression was very low compared with the levels of expression of 


\section{$\begin{array}{llllll}1 & 2 & 3 & 4 & 5 & 6\end{array}$}
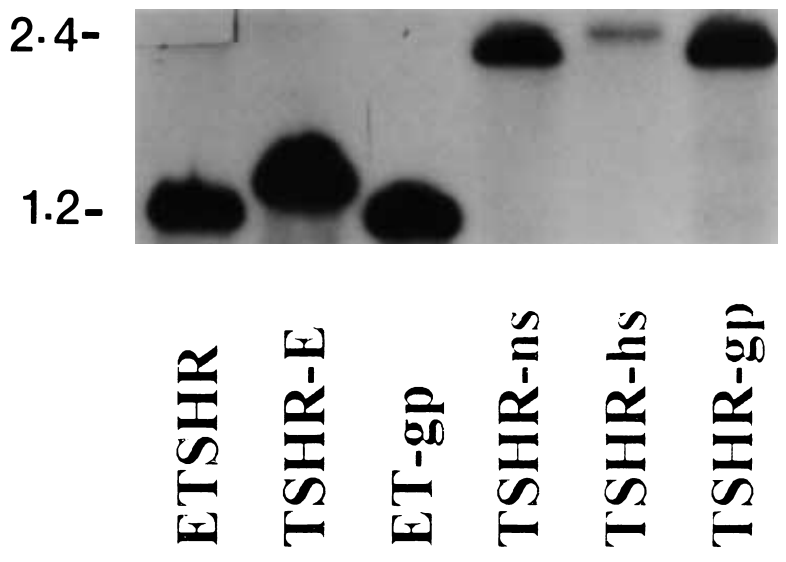

FIGURE 3. Southern blot analysis of DNA from recombinant virus infected Sf9 cells. DNA was isolated, electrophoresed, transferred onto nylon membrane and probed as described under Materials and Methods. The autoradiogram was developed after exposure for $4 \mathrm{~h}$. Lanes 1-6 represent ETSHR, TSHR-E, ET-gp, TSHR-ns, TSHR-hs and TSHR-gp respectively.

corresponding ectodomains of TSHR protein. Therefore, to see whether differences in replication potential could explain the differences in the level of protein expression, we tested the replicative ability of all six TSHR recombinant viruses. The titers of different recombinant viruses were comparable and ranged from $10^{-3}$ to $10^{-4}$. To compensate for small differences in viral titers, insect cells were infected with different recombinant viruses with the same multiplicity of infection (i.e. MOI of 1). Southern blot analysis, at $48 \mathrm{~h}$ post-infection, showed expected size DNA of almost equal intensity from all recombinant virus infected insect cells (Fig. 3) with the exception of cells infected with full-length TSHR cDNA containing human TSHR signal sequence (Fig. 3, lane 5).

Next, to see whether differences in the efficiency of transcription could account for different levels of protein expression, we carried out Northern blot analysis. Northern blot analysis of RNA from Sf9 cells infected with different recombinant viruses encoding extracellular domain of TSHR showed similar amounts of TSHR transcripts at all time points (Fig. 4A). However, cells infected with TSHR-hs virus showed consistently lower amounts of RNA compared with TSHR-ns and TSHR-gp virus infected insect cells at all time points (Fig. 4C). This is consistent with the lower levels of DNA seen in TSHR-hs virus infected cells.

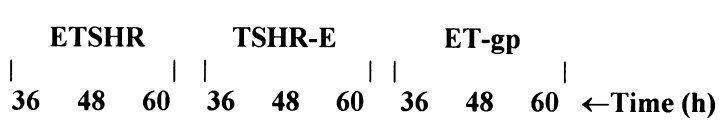

$\mathbf{A}$

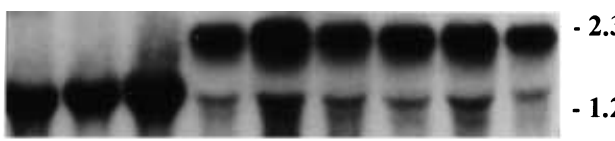

2.3

1.2

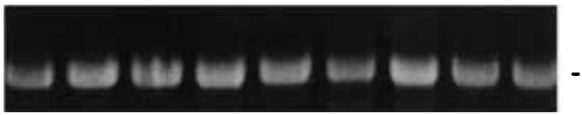

$-18 S$

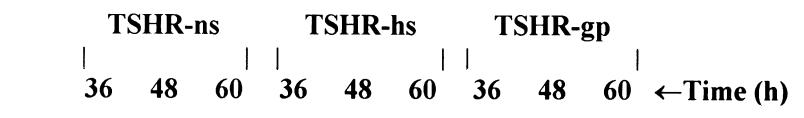

C

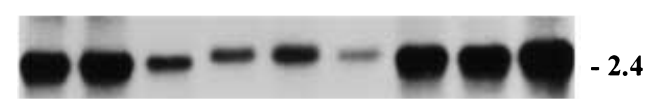

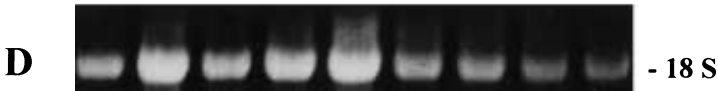

FIGURE 4. Northern blot analysis of RNA from recombinant virus infected Sf9 cells. Total RNA was isolated, electrophoresed, transferred into nylon membrane and probed as described under Materials and Methods. Upper (A and B) and lower panels (C and D) represent ectodomain and full-length TSHR constructs respectively. (A) and (C) represent autoradiograms developed after 6 and $10 \mathrm{~h}$ exposure respectively. (B) and (D) represent corresponding ethidium bromide stained gels before transferring onto nylon membrane. The enzymes used to digest the DNA are BamHI for ETSHR and ET-gp; EcoRI for TSHR-hs; and BamHI and EcoRI for TSHR-E, TSHR-ns and TSHR-gp.

\section{DISCUSSION}

A wide range of studies on thyroid require large quantities of relatively pure, functional TSHR. Because of lower levels of TSHR expression on thyrocytes, it has not been possible to purify the native receptor. Therefore, many laboratories, including our own, have attempted to generate recombinant TSHR protein (Takai et al. 1991, Harfst et al. 1992a,b,c, Huang et al. 1992, 1993, Seetharamaiah et al. 1993, 1997, Shi et al. 1993, Costagliola et al. 1994, Misrahi et al. 1994, Chazenbalk \& Rapoport 1995, Graves et al. 1995, Matsuba et al. 1995, Vlase et al. 1995, Rapoport et al. 1996, Osuga et al. 1997). Unfortunately, to date, all efforts to produce high levels of full-length recombinant TSHR protein, using different expression systems, have failed (Harfst et al. 1992a, Huang et al. 1993, Seetharamaiah et al. 1993, 
Misrahi et al. 1994, Chazenbalk \& Rapoport 1995). In this study, like in an earlier study (Misrahi et al. 1994), we were able to express low levels of full-length hTSHR using a baculovirus expression system. Unlike the full-length protein, we could readily produce relatively higher levels of ectodomains of TSHR. These studies confirmed our earlier observation that lack of signal sequence or replacement of human signal sequence with gp67 signal sequence could lead to enhanced production of ectodomain of TSHR (Seetharamaiah et al. 1997). Therefore, we expressed full-length receptor protein either without signal sequence or with gp67 signal sequence. Neither of these modifications resulted in enhanced full-length protein production. Even using a sensitive Western blot staining the protein cannot be detected earlier than $48 \mathrm{~h}$ post-infection and the mRNA levels reached significant levels by $36 \mathrm{~h}$ post-infection. This suggests that the transcripts appear at least $12 \mathrm{~h}$ before we can detect the protein. As shown in Fig. 2, full-length TSHR protein could be detected around $48-72 \mathrm{~h}$ post infection, and the protein expression did not increase after 3 days. Glycosylated full-length TSHR proteins, although produced at low levels, were able to neutralize autoantibodies to TSHR in the sera of patients with autoimmune thyroid disease.

Because of very low levels of full-length protein expression, we wondered whether there were differences in the replicative ability of different recombinant baculoviruses. We determined the titer of different viruses at different intervals after infection and found that there were no significant differences. Next, we looked at the level of viral DNA and found that there was no correlation between the levels of viral DNA and protein. For example, all cells infected with recombinant viruses encoding different ectodomains exhibited similar levels of DNA and yet TSHR-E expression was lower. Similarly, the levels of TSHR-gp and TSHR-ns DNA were high relative to TSHR-hs and yet none of them was expressed at a higher level. These results indicated that differences in the DNA levels may not account for differences in the amounts of protein.

Level of protein expression is often reflected by the amount of mRNA present in the cell. Messenger RNA level is regulated either by the rate of transcription or by the stability of mRNA. To see whether differential regulation of TSHR specific transcripts could be responsible for differences in the levels of expression of full-length TSHR and their corresponding ectodomains, we performed Northern blot analysis. Northern analyses showed that there were considerable amounts of transcripts at all times in all cells irrespective of the recombinant virus used for infection. The levels of mRNA from full-length TSHR-expressing cells were comparable to the levels of mRNA in cells expressing corresponding ectodomains at all three time points, i.e. 36,48 and $60 \mathrm{~h}$ post-infection, and still the full-length protein expression remained low. In contrast, ectodomain proteins reached maximal levels by $60-72 \mathrm{~h}$. Our data showed that, in spite of stable mRNA levels, the levels of fulllength TSHR protein expression did not increase over time. These data suggested that the protein expression is regulated at a step subsequent to transcription.

Length of non-coding upstream sequences can affect the level of protein production (Matsura et al. 1987). However, based on our current results it is unlikely that 100 bases of $5^{\prime}$ upstream non-coding sequence found in TSHR-hs significantly affected the protein production. This suggestion is based on the observation that there were no differences in the level of TSHR expression among different fulllength TSHR constructs with or without the upstream sequence. More recently, studies using cell-free translation system have clearly shown that the length of poly(A) tail can have significant influence on translation by recruiting ribosome and allowing translation of uncapped mRNA (Gallie 1991, Iizuka et al. 1994, Tarun \& Sachs 1995, Sachs et al. 1997, Preiss \& Hentze 1998). These observations are consistent with observations in vivo where cap structure and poly(A) have been shown to have synergistic effect. We could rule out the influence of poly(A) tail on full-length TSHR protein production, since we used only cDNAs for protein expression.

In eukaryotic cells, cap structure at the $5^{\prime}$ end of the mRNA determines the amount and quality of the protein produced (Preiss \& Hentze 1998). This is primarily accomplished by enhancing the translational initiation frequency and recruiting $40 \mathrm{~S}$ ribosomal subunit to sites that are proximal to the $5^{\prime}$ end of the mRNA. However, some mRNAs contain internal ribosomal entry sites (IRESs) to which ribosomes can bind and influence translation (Pelletier \& Sonenberg 1988). This occurs even when the $5^{\prime}$ is either blocked or uncapped. The cap structure may not account for differences in the levels of protein production because the $5^{\prime}$ ends of cDNAs are identical in corresponding ETSHR and full-length TSHR constructs. Again the $5^{\prime}$ ends of cDNAs used for generating all six recombinant viruses are identical and, therefore, differences in IRES, if any, should reside in the $3^{\prime}$ end of the cDNA. Another factor that controls the translational efficiency is the mRNA secondary structure (Londei 1998). The eukaryotic 
initiation factor (eIF), eIF4F, is a complex of three polypeptides, eIF4E, eIF4A and eIF4G and facilitates the ATP-dependent unfolding of the mRNA secondary structure (Londei 1998). The eIF4G acts as an adaptor, which couples the cap-recognition function of eIF4E to the helicase function of eIF4A. If any of these initiation factors do not function optimally, then complex RNA secondary structure will be maintained, thus negatively affecting the translational efficiency. At the present time, we do not know how the TSHR protein production is translationally regulated. Therefore, understanding what role any of these structures play in the translation of TSHR might help us not only to produce larger quantities of full-length protein but, more importantly, the regulation of TSHR expression.

\section{ACKNOWLEDGEMENTS}

We thank Drs K Tahara and L D Kohn, NIDDK, National Institutes of Health, for providing the human TSHR cDNA. This work was supported in part by National Institutes of Health Grant DK47417 and DK44972

\section{REFERENCES}

Chazenbalk GD \& Rapoport B 1995 Expression of the extracellular domain of the thyrotropin receptor in the baculovirus system using a promoter active earlier than the polyhedrin promoter. Fournal of Biological Chemistry 270 1543-1549.

Chazenbalk GD, Kakinuma A, Jaume JC, McLachlan SM \& Rapoport B 1996 Evidence for negative cooperativity among human thyrotropin receptors overexpressed in mammalian cells. Endocrinology 137 4586-4591.

Costagliola S, Alcalde L, Ruf J, Vassart G \& Ludgate M 1994 Overexpression of the extracellular domain of the thyrotropin receptor in bacteria; production of thyrotropin-binding inhibiting immunoglobulins. Fournal of Molecular Endocrinology 13 11-21.

Costagliola S, Khoo D \& Vassart G 1998 Production of bioactive amino-terminal domain of the thyrotropin receptor via insertion in the plasma membrane by a glycosylphosphatidylinositol anchor. FEBS Letters 436 427-433.

Da Costa CR \& Johnstone AP 1998 Production of thyrotropin receptor extracellular domain as a glycosylphosphatidylinositolanchored membrane protein and its interaction with thyrotropin and autoantibodies. Fournal of Biological Chemistry 273 11874-11880.

Filetti S, Foti D, Costante G \& Rapoport B 1991 Recombinant human TSH receptor in a radioreceptor assay for the measurement of TSH receptor autoantibodies. Fournal of Clinical Endocrinology and Metabolism 72 1096-1101.

Gallie DR 1991 The cap and poly (A) tail function synergistically to regulate mRNA translational efficiency. Genes and Development 5 2108-2116.

Graves PN, Vlase H \& Davies TF 1995 Folding of the human recombinant human thyrotropin receptor: identification of folded monomeric and tetrameric complexes that bind TSH receptor autoantibodies. Endocrinology 136 521-527.
Harfst E, Johnstone AP, Gout I, Taylor AH, Waterfield MD \& Nussey SS $1992 a$ The use of the amplifiable high-expression vector pEE14 to study the interactions of autoantibodies with recombinant human thyrotropin receptor. Molecular and Cellular Endocrinology 83 117-123.

Harfst E, Johnstone AP \& Nussey SS $1992 b$ Characterization of the extracellular region of the human thyrotropin receptor expressed as a recombinant protein. Fournal of Molecular Endocrinology 9 227-236.

Harfst E, Johnstone AP \& Nussey SS 1992c Interaction of thyrotropin and thyroid-stimulating antibodies with recombinant extracellular region of human TSH receptor. The Lancet 339 193-194.

Huang GC, Collison KS, McGregor AM \& Banga JP 1992 Expression of a human thyrotropin receptor fragment in Escherichia coli and its interaction with the hormone and autoantibodies from patients with Graves' disease. Fournal of Molecular Endocrinology 8 137-144.

Huang GC, Page MJ, Nicholson LB, Collison KS, McGregor AM \& Banga JP 1993 The thyrotropin hormone receptor of Graves' disease: overexpression of the extracellular domain in insect cells using recombinant baculovirus, immunoaffinity purification and analysis of autoantibody binding. Fournal of Molecular Endocrinology 10 127-142.

Iizuka N, Najita L, Franzusoff A \& Sarnow P 1994 Capdependent and Cap-independent translation by internal initiation of mRNAs in cell extracts prepared from Saccharomyces cervisiae. Molecular and Cellular Biology 14 7322-7330.

Kohn LD, Shimura H, Shimura Y, Hidaka A, Giuliani C, Napolitano G, Ohmori M, Laglia G \& Saji M 1995 The thyrotropin receptor. Vitamins and Hormones 50 287-385.

Londei P 1998 A hypothesis on the mechanism of translational initiation. Biochimica et Biophysica Acta 1396 169-178.

Ludgate M, Perret J, Parmentier M, Gerard C, Libert F, Dumont JE \& Vassart G 1990 Use of the recombinant human thyrotropin receptor (TSH-R) expressed in mammalian cell lines to assay TSH-R autoantibodies. Molecular and Cellular Endocrinology 73 R13-R18.

Matsuba T, Yamada M, Suzuki H, Kanai A, Isozaki O, Yoshida T, Tsushima T \& Yasukawa K 1995 Expression of recombinant human thyrotropin receptor in myeloma cells. Fournal of Biochemistry 118 265-270.

Matsura Y, Possee RD, Overton HA \& Bishop DHL 1987 Baculovirus expression vectors: the requirements for high level expression of proteins, including glycoproteins. Fournal of General Virology 68 1233-1250.

Memar OM, Rajaraman S, Thotakura R, Tyring SK, Fan JL, Seetharamaiah GS, Lopez A, Jordon RE \& Prabhakar BS 1996 Recombinant desmoglein 3 has the necessary epitopes to adsorb and induce blister-causing antibodies. Fournal of Investigative Dermatology 406 261-268.

Misrahi M, Ghinea N, Sar S, Saunier B, Jolivet A, Loosefelt H, Cerutti M, Devauchelle G \& Milgrom E 1994 Processing of the precursors of the human thyroid-stimulating hormone receptor in various eukaryotic cells (human thyrocytes, transfected L cells and baculovirus-infected insect cells). European Fournal of Biochemistry 222 711-719.

Nagayama Y \& Rapoport B 1992 The thyrotropin receptor 25 years after its discovery: new insight after its molecular cloning. Molecular Endocrinology 6 145-156.

Nagayama Y, Kaufman KD, Seto P \& Rapoport B 1989 Molecular cloning, sequence and functional expression of the cDNA for the human thyrotropin receptor. Biochemical and Biophysical Research Communications 165 1184-1190.

Osuga Y, Kudo MM, Kaipia A, Kobilka B \& Hsueh AJW 1997 Derivation of functional antagonists domain of gonadotropin 
and thyrotropin receptors. Molecular Endocrinology 11 1659-1668.

Pelletier J \& Sonenberg N 1988 Internal initiation of translation of eukaryotic mRNA directed by a sequence derived from poliovirus RNA. Nature 334 320-325.

Perret J, Ludgate M, Libert F, Gerard C, Dumont JE, Vassart G \& Parmentier M 1990 Stable expression of human TSH receptor in $\mathrm{CHO}$ cells and characterization of differentially expressing clones. Biochemical and Biophysical Research Communications 171 1044-1050.

Prabhakar BS, Fan JL \& Seetharamaiah GS 1997 Thyrotropinreceptor-mediated diseases: a paradigm for receptor autoimmunity. Immunology Today 18 437-442.

Preiss T \& Hentze MW 1998 Dual function of the messenger RNA cap structure in poly(A)-tail-promoted translation in yeast. Nature $392516-520$.

Rapoport B, McLachlan SM, Kakinuma A \& Chazenbalk GD 1996 Critical relationship between autoantibody recognition and thyrotropin receptor maturation as reflected in the acquisition of complex carbohydrate. Fournal of Clinical Endocrinology and Metabolism 81 2525-2533.

Sachs AB, Sarnow P \& Hentze MW 1997 Starting at the beginning, middle, and end: translation initiation in eukaryotes. Cell 89 831-838.

Sambrook J, Fritsch EF \& Maniatis T 1989 Analysis and cloning of eukaryotic genomic DNA. In Molecular Cloning: A Laboratory Manual, vol 2, pp 9·31-9.58. Ed C Nolan. New York: Cold Spring Harbor Laboratory Press.

Seetharamaiah GS, Desai RK, Dallas JS, Tahara K, Kohn LD \& Prabhakar BS 1993 Induction of TSH binding inhibitory immunoglobulins with the extracellular domain of human thyrotropin receptor produced using baculovirus expression system. Autoimmunity 14 315-320.

Seetharamaiah GS, Kurosky A, Desai RK, Dallas JS \& Prabhakar BS 1994 A recombinant extracellular domain of the thyrotropin (TSH) receptor binds $\mathrm{TSH}$ in the absence of membranes. Endocrinology 134 549-554.

Seetharamaiah GS, Wagle NM, Morris JC \& Prabhakar BS 1995 Generation and characterization of monoclonal antibodies to the human thyrotropin (TSH) receptor: antibodies can bind to discrete conformational or linear epitopes and block TSH binding. Endocrinology 136 2817-2824.

Seetharamaiah GS, Dallas JS, Patibandla SA, Thotakura NR \& Prabhakar BS 1997 Requirement of glycosylation of the human thyrotropin receptor ectodomain for its reactivity with autoantibodies in patients' sera. Fournal of Immunology 158 2798-2804.

Seetharamaiah GS, Dallas JS \& Prabhakar BS 1999 Glycosylated ectodomain of the human thyrotropin receptor induces antibodies capable of reacting with multiple blocking antibody epitopes. Autoimmunity 29 21-31.

Shi Y, Zou M, Parhar RS \& Farid NR 1993 High-affinity binding of thyrotropin to the extracellular domain of its receptor transfected in Chinese hamster ovary cells. Thyroid 3 129-133.

Summers MD \& Smith GE 1987 A manual of methods for baculovirus vectors and insect cell culture procedures. Bulletin no. 1555, Texas Agricultural Experiment Station, College Station, Texas.

Tahara K, Ban T, Minegishi T \& Kohn LD 1991 Immunoglobulins from Graves' disease patients interact with different sites on TSH receptor/LH-CG receptor chimeras than either TSH or immunoglobulins from idiopathic myxedema patients. Biochemical and Biophysical Research Communications 179 70-77.

Takai O, Desai RK, Seetharamaiah GS, Jones CA, Allaway GP, Akamizu T, Kohn LD \& Prabhakar BS 1991 Prokaryotic expression of the thyrotropin receptor and identification of an immunogenic region of the protein using synthetic peptides. Biochemical and Biophysical Research Communications 179 319-326.

Tarun SZ Jr \& Sachs AB 1995 A common function for mRNA $5^{\prime}$ and $3^{\prime}$ ends in translation initiation in yeast. Genes and Development 9 2997-3007.

Vassart G \& Dumont JE 1992 The thyrotropin receptor and the regulation of the thyrocyte function and growth. Endocrine Reviews 13 61-76.

Vlase H, Graves PN, Magnusson RP \& Davis TF 1995 Human autoantibodies to the thyrotropin receptor: recognition of linear, folded, and glycosylated recombinant extracellular domain. Fournal of Clinical Endocrinology and Metabolism 80 46-53.

Whetsell M, Bagriacik EU, Seetharamaiah GS, Prabhakar BS \& Klein JR 1999 Neuroendocrine-induced synthesis of bone marrow-derived cytokines with inflammatory immunomodulating properties. Cellular Immunology 192 159-166.

REVISED MANUSCRIPT RECEIVED 9 July 1999 